\title{
Cognitive Learning Styles Used by Male and Female Students in Grade 10 of Natural Science of " $X$ " School in Surabaya
}

\author{
Febe Eka Widarma \\ English Department, Faculty of Languages and Literature, Petra Christian University, Siwalankerto 121-131, \\ Surabaya 60236, INDONESIA \\ Email: m11415053@john.petra.ac.id; febe238@gmail.com
}

\begin{abstract}
This study identifed male and female's cognitive learning styles and found out the differences and similarities the cognitive learning styles between male and female students in grade 10 of "X"school in Surabaya. There were twenty six students in Natural Science class (X-IPA1). The main theory for this study is from Ehrman (1996) about Cognitive Learning Styles. The method was mixed-methods. The researcher distributed questionnaires adapted from Ehrman and Leaver (2002b) ind interview to the students in order to know their cognitive learning styles. The findings showed that male students were concrete and female students were analog learners. Additionally, the finding also showed that the male and female students had five similarities and five differences. English teachers will be easier to conduct classroom activites based on the findings of male and female students' cognitive learning styles.
\end{abstract}

Key words: Cognitive learning styles, learning style, gender

\section{INTRODUCTION}

Cognitive learning style plays an important role in a learner's language learning process. Cognitive learning style is a permanent characteristic of personality (Cheeme \& Ridding, 1991; Curry, 1983). Over the years, the cognitive style has become a crucial aspect of learning style because cognitive learning style has "great contributions to second language acquisition" (Tang, 2009, p. 129).

The researcher wanted to find out the differences and similarities between male and female students' cognitive learning styles. Some studies show that gender could determine or influence the learning styles of each individual. A study conducted by Soozandehfar (2011) shows that female learners appear to be more field-independent than male learners.

The researcher chose students who were in grade 10 because she wanted to enhance students' learning for the next stages; grade 11 and grade 12. In order to do it, early diagnostic of students' cognitive learning styles in grade 10th is highly demanded, leading to incorporation of learning strategies. Natural science class (IPA) was chosen because these students got the highest scores in Language subject in National Exam (Yayasan Trakanita, 2012).

In this study, the researcher aims to identify male and female students' cognitive learning styles and find out the differences and similarities between male and female students' cognitive learning styles. She conducts questionnaire written by Ehrman and Leaver (2002) which contains of ten sub-scales of cognitive learning styles. Furthermore, to get the information about cognitive learning styles used by "X" school students, The researcher conducts interview to $30 \%$ of each gender which are five male students and three female students.

In answering the research questions, the researcher used Ehrman theory. Ehrman (1996) proposed ten sub-scales of cognitive learning styles in table 1 below.

Table 1.1 Ten Sub-Scales of Cognitive Learning Styles (Ehrman, 1996)

\begin{tabular}{|c|c|c|c|}
\hline No & $\begin{array}{l}\text { Sub- } \\
\text { scales }\end{array}$ & & \\
\hline 1. & $\begin{array}{l}\text { Field- } \\
\text { sensitivity }\end{array}$ & $\begin{array}{l}\text { Field } \\
\text { Sensitive } \\
\text { (FS) }\end{array}$ & $\begin{array}{l}\text { The students pick up material as part of context by process. } \\
\text { The students will not use the whole context from the } \\
\text { material. }\end{array}$ \\
\hline
\end{tabular}




\begin{tabular}{|c|c|c|c|}
\hline & & $\begin{array}{l}\text { Field } \\
\text { Insensitive } \\
\text { (FIns) }\end{array}$ & \\
\hline 2. & $\begin{array}{l}\text { Field- } \\
\text { Dependence }\end{array}$ & $\begin{array}{l}\text { Field } \\
\text { Independent } \\
\text { (FI) } \\
\text { Field } \\
\text { Dependent } \\
\text { (FD) }\end{array}$ & $\begin{array}{l}\text { The students are able to cut information and do more with } \\
\text { it. } \\
\text { The students are dealing with information by never trying } \\
\text { to select out anything from the material for his or her focus. }\end{array}$ \\
\hline 3. & $\begin{array}{l}\text { Differentiatio } \\
\mathrm{n}\end{array}$ & $\begin{array}{l}\text { Leveling } \\
\text { Sharpening }\end{array}$ & $\begin{array}{l}\text { Levelers tend to remove the distinctions and seek the } \\
\text { similatities. } \\
\text { Sharpeners are looking for the dictinctions than } \\
\text { similarities. }\end{array}$ \\
\hline 4. & Detaildness & $\begin{array}{l}\text { Global } \\
\text { Particular }\end{array}$ & $\begin{array}{l}\text { They focus on the big picture. } \\
\text { They will see the form first and the general meaning } \\
\text { second. }\end{array}$ \\
\hline 5. & $\begin{array}{l}\text { Conceptual } \\
\text { Tempo }\end{array}$ & $\begin{array}{l}\text { Impulsive } \\
\text { Reflective }\end{array}$ & $\begin{array}{l}\text { The students tend to focus on the speed and manner of } \\
\text { processing a response to a cognitive stimulus "fast." } \\
\text { The students prefer to take everything into consideration } \\
\text { first and then answer or respond the questions "slow." }\end{array}$ \\
\hline 6. & Syntheciticity & $\begin{array}{l}\text { Synthetic } \\
\text { Analytic }\end{array}$ & $\begin{array}{l}\text { Synthetic learners are able to put together pieces into one. } \\
\text { They receive any information from many sources to make } \\
\text { new thing with them. } \\
\text { Analytic learners prefer to break wholes into pieces. }\end{array}$ \\
\hline 7. & Metaphoricity & Analog & $\begin{array}{l}\text { They like to learn throughdeveloping and applying } \\
\text { methephors or analogies to their learning because they like } \\
\text { association and elaboration. } \\
\text { They want to deal with infromation based on what they are } \\
\text { hearing and seeing }\end{array}$ \\
\hline 8. & Concreteness & $\begin{array}{l}\text { Concerete } \\
\text { Abstract }\end{array}$ & $\begin{array}{l}\text { The students prefer to interact with the world directly } \\
\text { through "experinces." } \\
\text { The students tend to learn from the theory (they tend to } \\
\text { think about grammar rule) }\end{array}$ \\
\hline 9. & Sequentiality & $\begin{array}{l}\text { Random } \\
\text { Sequential }\end{array}$ & $\begin{array}{l}\text { These students will do the same things in order to find } \\
\text { information and make connections between new and old } \\
\text { knowledge. } \\
\text { These students will learn step-by-step or follow the } \\
\text { textbook. }\end{array}$ \\
\hline 10. & $\begin{array}{l}\text { Inductive- } \\
\text { Deductive }\end{array}$ & $\begin{array}{l}\text { Inductive } \\
\text { Deductive }\end{array}$ & $\begin{array}{l}\text { They like to create hypotheses first and then finally test it. } \\
\text { They tend to start with theories and practice applying them } \\
\text { to examples. }\end{array}$ \\
\hline
\end{tabular}

\section{DATA COLLECTION}

In this study, the researcher used mixed methods where the quantitative and qualitative principles were combined at the data analysis stage by quantifying the data. The researcher used questionnaires and semi-structured interviews. The researcher distributed the questionnaires to the 10th-grade students of Natural Science (X-IPA1) of "X" school in Surabaya and the duration for completing the questionnaire was approximately 30 minutes. The questionnaire was translated into Bahasa Indonesia to avoid misuderstanding and time-consumption. For the interview, the researcher also gave code, for example, I stands for the interviewer. The codes for the interviewees are, A1, A2, A3, and so on (male students), meanwhile, B1, B2, B3, and so on (female students). The problem for this study was that the duration given to do the interview. On the interview day, the researcher was only given fifteen minutes for each gender, so the researcher had to ask the only certain questions to each student randomly. The question was as follow : 
Table 1.2 Questions for Interview

\begin{tabular}{|c|l|}
\hline Students & \multicolumn{1}{c|}{ Questions } \\
\hline A2 (Male) & Questions number 9 and 10 \\
\hline A5 (Male) & Questions number 3, 4, 6, and 7 \\
\hline A11 (Male) & Questions number 8, 9, and 10 \\
\hline A10 (Male) & Questions number 1,2,3, 4, 5, 6, 7, and 9 \\
\hline A13 (Male) & Questions number 1, 3, 4, 5, 6, 8, 9, and 10 \\
\hline B3 (Female) & Questions number 1, 3, 5, 7, and 10 \\
\hline B5 (Female) & Questions number 2, 3, 4, 5, 7, 8, and 9 \\
\hline B6 (Female) & Questions number 1,3, 4, 5, 6, 7, and 9 \\
\hline
\end{tabular}

The researcher used the table in order to ask the questions to the certain students. Then, the results were used to give data in findings and discussion.

\section{DATA ANALYSIS}

After the questionnaire was filled by the respondents, the researcher collected it. Then, the researcher assigned codes to differentiate the gender of each student. The codes were the same as the codes for the interview data.

The researcher classified the questions based on the sub-scales of cognitive learning styles. She classified question numbers 1,11 , and 21 (field sensitivity); question numbers 2, 12, and 22 (field dependence); question numbers 3, 13, and 23 (differentiation); question numbers 4, 14, and 24 (detaildness); question numbers 5, 15, and 25 (conceptual tempo); question numbers 6, 16, and 26 (syntheciticity); question numbers 7, 17, and 27 (methaphoricity); questions numbers 8, 18, and 28 (concreteness); questions number 9, 19, and 29 (sequentiality); and question numbers 10, 20, and 30 (inductive-deductive).

Subsequently, the researcher enteried the students' answer to Microsoft Excel. The excel provided formulas to calculate the results on it. In order to use Microsoft Excel, the researcher inputted the students' answer on the individual category responses section. She filled the students' answers on X1, X2, and X3 based on the scale of the questionnaire which was from 1 to 9 . Then, the sum or raw was filled in automatically which got from $\mathrm{X} 1+\mathrm{X} 2+\mathrm{X} 3$. In order to get the average, the sum was divided by the total of questions for each sub-scale which contained three questions (from $\mathrm{X} 1, \mathrm{X} 2$, and X3). Based on the excel's table, so the researcher did not modify anything.

\section{Notes:}

X1: The questions number 1-10 (questionnaire), X2: The questions number 11-20 (questionnaire), and X3: The questions number 21-30 (questionnaire)

After calculating the results of the questionnaire, the researcher used table 1.3 to get the male and female's cognitive learning styles. For example, she used the male students' table to find out their cognitive learning styles. The researcher filled in the columns listed in A1, A2, A3, ... and A15 with the sum of each male student' results of each sub-scale in the Microsoft Excel.

Table 1.3 Table for Male's Cognitive Learning Styles

\begin{tabular}{|c|c|c|c|c|c|c|c|c|}
\hline 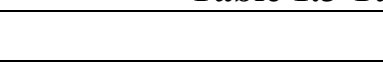 & A1 & $\mathbf{A 2}$ & $\mathbf{A 3}$ & $\ldots$ & $\ldots$ & $\mathbf{A 1 5}$ & SUM & Avg \\
\hline 1.Field sensitivity & & & & & & & $\begin{array}{c}\text { Sum 1 = } \\
\mathrm{A} 1+\mathrm{A} 2+\mathrm{A} 3+\ldots+\mathrm{A} 15\end{array}$ & $\begin{array}{c}\text { Avg 1 = } \\
\text { Sum 1 } \\
\text { The total of } \\
\text { male students }\end{array}$ \\
\hline$\ldots$ & $\ldots$ & $\ldots$ & $\ldots$ & $\ldots$ & $\ldots$ & $\ldots$ & $\ldots$ & $\ldots$ \\
\hline 10. Deductive-Inductive & & & & & & & $\begin{array}{c}\text { Sum 10 = } \\
\mathbf{A} 1+\mathbf{A 2}+\mathbf{A} 3+\ldots+\mathbf{A 1 5}\end{array}$ & $\begin{array}{c}\text { Avg } 10= \\
\text { Sum } 10 \\
\text { The total of } \\
\text { male students }\end{array}$ \\
\hline
\end{tabular}


Notes:

A1-A15 : The total of male students

Sum : The total of male students' sub-scales

Avg : The average of male students' sub-scales

$$
\begin{aligned}
\text { Sum } & =\mathbf{A} 1+\mathbf{A} 2+\mathbf{A} 3+\ldots . .+\mathrm{A} 15 \\
\mathrm{Avg} & =\frac{\text { Sum }}{\text { The total of male students }}
\end{aligned}
$$

Table 1.3 was the example for field sensitivity. The researcher also used the same table and formula for calculating the other sub-scales. In order to find out female's cognitive learning styles, the researcher also used thesame the same table and formula. The researcher got sum above was from the total of $\mathrm{A} 1+\mathrm{A} 2+\mathrm{A} 3+\ldots+\mathrm{A} 15$. For avg, it was got from SUM divided by the total of male students.

For this questionnaire, Ehrman and Leaver (2002a) provide a scoring key to interpret the results. For instance, the total from question numbers 1, 11, and 21 have to be added; students with a score of 1-15 are labelled as field sensitive and the students with a score of 16-30 are as field insensitive. Students with a score of 15,1-15,4 are labelled as field sensitive. Students with a score of 15,5-15,9 are as field insensitive.

After the researcher did the interpretation of the Microsoft Excel and table 1.3, the researcher used the final average score in table differences and similarities of cognitive learning styles used by between male and female students.

\section{FINDINGS AND DISCUSSION}

The researcher used the findings of the questionnaire in table 1.5 below and interview to answer the research questions.

Table 1.4 The Average of Male Students' Cognitive Learning Styles

\begin{tabular}{|l|l|l|}
\hline Sub-scales & Avg & \\
\hline 1.Field sensitivity & 14,9 & $\begin{array}{l}\text { Field } \\
\text { Sensitive }\end{array}$ \\
\hline 2.Field dependence & 14,1 & $\begin{array}{l}\text { Field } \\
\text { Independent }\end{array}$ \\
\hline 3.Differentiation & 14,6 & Leveling \\
\hline 4.Detailedness & 14,8 & Global \\
\hline 5.Conceptual tempo & 16,3 & Reflective \\
\hline 6.Syntheciticity & 15,9 & Analytic \\
\hline 7.Metaphoricity & 18,7 & Digital \\
\hline 8. Concreteness & 11,5 & Concrete \\
\hline 9. Sequentiality & 16,1 & Sequential \\
\hline 10.Inductive-deductive & 16,3 & Deductive \\
\hline
\end{tabular}

Table 1.5 The Average of Female Students' Cognitive Learning Styles

\begin{tabular}{|l|l|l|}
\hline Sub-scales & Avg & \\
\hline 1.Field sensitivity & 11,1 & $\begin{array}{l}\text { Field } \\
\text { Sensitive }\end{array}$ \\
\hline 2.Field dependence & 9,7 & $\begin{array}{l}\text { Field } \\
\text { Independent }\end{array}$ \\
\hline 3.Differentiation & 11,8 & Leveling \\
\hline 4.Detailedness & 10,0 & Global \\
\hline 5.Conceptual tempo & 12,1 & Impulsive \\
\hline 6.Syntheciticity & 11,0 & Synthetic \\
\hline 7.Metaphoricity & 13,9 & Analog \\
\hline 8. Concreteness & 8,5 & Concrete \\
\hline 9. Sequentiality & 11,9 & Random \\
\hline 10.Inductive-deductive & 10,1 & Inductive \\
\hline
\end{tabular}

Table 1.4 and 1.5 showed that there were five differences and five similarities between male and female students' cognitive learning styles. There were two sub-catagories which were differences and similarities. The detailed findings would be discussed in the following paragraphs:

\section{A. Differences}

In conceptual tempo, male students were more reflective (16,3) than female students. Males was indicated as reflective learners because in the interview student A10 (male) said "...membaca ulang-ulang setiap soal dan jawaban untuk mengecek dan memastikan kalau itu gak salah. ” (“...read each question several times and answer time after time in order to make sure or check that the answers 
are not wrong"). Student A10 was indicated as a relative learner because he said "ulang-ulang, mengecek, and memastikan" ("several time, check, and make sure"). Those words showed the characteristics of relative learners. They will spend a lot of time to do their exercises (Ehrman, 1996). In contrast, female students were more impulsive. Student B6 (female) said "Biasanya cepat sih...kerja soal itu Cuma sesuai feeling.." ("Usually, I finish it fast...do the exercises using feeling..."). The words "feeling" indicated impulsive. Student B6 did not need a lot of time to do the exercises because she did not care whether her answers were correct or not as long as she could finish it fast (Ehrman, 1996).

In syntheciticity, male and female also had the differences. Males were analytic $(15,9)$ because Student A6 (male) said "Aku biasanya saya suka baca buku cerita bahasa Inggris, kalau sebelum baca, saya selalu mencari kata-kata susah di google, trus barulah saya akan baca keseluruhannya biar gak susah" ("Usually I like reading English stories. Before reading, I always look for the difficult words in google first to make it easy understand, after that, I will read the whole story"). Student A6 was categorized as an analytic learner because he does preparation before reading the whole stories. He marked certain words or difficult words and looked for the meaning on the internet first. Then, the lanalytic kearners would not have any difficulties in understanding the whole meaning. He did it because he wanted to be fast in reading. It is the same as an Ehrman's example. Analytic students asked to read materials and evaluate them and complete a task. They are allowed to use dictionaries. Then, they will like to list words that they want to look up quickly so that they become quite proficient at rapid page turning (Ehrman, 1996). While, females were synthetic $(11,0)$. Females tend to deal with any information from different sources. Student B6 (female) stated "...aku suka nonton Harry Potter sama baca bukunya..aku pakai bahasa-bahasa di situ sebagai contohcontoh untuk belajar Bahasa Inggris. " ("...I like watching the film and reading the book of Harry Potter...I use the language as the exemples in learning English"). She did not just learn English at school, but she also tried to improve her English skills outside classroom through watching movies and reading the books of her favorite one. Then, she used any structures that she got from the movies or books to create her own learning process.

In metaphoricity, males were digital $(18,7)$. It is because Student A13 (male) told that "Aku biasanya kalau belajar bahasa inggris kayak grammarnya lebih suka sama guru. Soalnya kata-kata yang dipakai biasanya yang saya tahu... saya jarang belajar grammar dari buku-buku lain" ("If I study English, I prefer to study it with my teacher especially for grammar. It is because the teacher uses common words....I rarely learn grammar from other books"). Those students are categorized as digital learners. Student A13 told that he preferred to learn grammar through his teacher's explanation. He did not want to find out the other explanation or examples from other recourses. He only received the information from what he heard (Ehrman, 1996). For females, they were analog $(13,9)$ when student B6 told in the previous paragraph. She applied everything that she got from watching and reading in her study. Ehrman (1996) stated that the learners "tend relatively to make association among the things they are learning."

In sequentiality, there were differences between male and female students. Male appeared more sequential $(16,1)$ than female $(11,9)$. Student A10 (male) said that “...tapi kadang saya gak paham maksudnya apa terus saya stop untuk cari kata-katanya di google, kalau sudah tahu, baru saya lanjut" ("...Sometimes, I do not know the words and I need to stop it to look for the words on the google, then, I continue"). From the interview, student A11 was categorized as sequential learner. He would spend much time to master one thing before going or jump to the next. (Ehrman, 1996, p. 13). Student B6 (female) stated “...cepat sih...kerja soal itu suma sesuai feeling.." (“...fast...do the exercises using feeling..."). She would like using random access in her learning process. It is very easy for sequential learners to find out one thing (Ehrman, 1996).

In inductive-deductive, Male students were inductive (16,3). Student A11 (male) said "Saya suka bermain online game yang bisa chattingan..."("I like playing online game which providing a room chat..."). Student A11 was keeping learning language although there was not a teacher with him. It is because the student has got enough theories of English forms. Then, he applied it to examples by playing online games. In the games, he would have communication with many people around the world using English. Basically, he is an independent learner (Ehrman, 1996). In contrast, female appeared more deductive $(16,3)$. As student B6 said before, she liked reading and watching. 
It means she tend to find some examples, then, apply it into theory. Then, the deductive learners will have big opportunitirs to improve their English skills.

\section{B. Similarities}

In similarities, the first one is field sensitivity. The results for male $(14,9)$ and female $(11,1)$ were the same which was field sensitive. Student A10 (male) said "...Jadi saya butuh bantuan teman untuk bisa menjawabnya dalam bahasa Inggris juga walaupun kadang grammar saya salah. ”(“...so, I needed a friend for helping me to answer or respond my teacher using English although the grammar is wrong"). From the interview, the researcher knew that the student was a field-sensitive learner because he tried to communicate with his teacher using English. He did not worry about his errors because the important thing for him is that the teacher can understand the meaning (Ehrman, 1996). For female, student B3 (female) said "Saya mudah menemukan kosakata baru, biasanya kalau lagi baca,..." ("It is easy for me to find out new vocabularies during reading..."). As field sensitive's characteristic, the field sensitive learners will be easier to find out new vocabularies in stories. Both of male and female students had the characteristics of field sensitive learners. They may not focus on grammar and have difficulties in finding new vocabularies.

In field dependence, male students were field-independent (14,1). Student A11 stated "Saya suka bermain online game yang bisa chattingan. Hampir teman yang saya dapat di game itu adalah orang-orang luar negeri. Mereka menggunakan bahasa Inggris saat bermain melalui chat." ("I like playing online game which providing a room chat. Almost all of my friends in the game are living abroad. They use English for communication during playing the game"). The statement showed that he was field-independent learners because he learnt English through online games. Student B6 (female) said "...aku suka baca dan nonton...” (“...I llike reading and watching..."). She improved her skill outside the classroom by reading and watching. Ehrman (1996) stated that the learners tend to have activities which can carry out alone. Male and female students had the characteristics.

In differentiation, male $(14,6)$ and female $(11,8)$ were levelers. Male students like to meld features memories together, but the way that they use is that looking for similarities (Ehrman, 1996). Student A10 (male) told that “..... Waktu SMP, guru saya memberi tugas untuk menemukan 5 kata baru setiap hari. Jadi, saya harus tahu artinya terlebih dulu kemudian tahu cara pakainya dan saya melakukannya sampai sekarang kak" (“... When I was in junior high school, my teacher gave an assignment to find out 5 new vocabularies every day. So, I had to know the meaning first. Then, I would be able to know how to use it and I have been using the technique until now"). The way that student A10 used in the past when he was junior high school to increase the new vocabularies was still the same. He still memorized and applied it. For female, student B6 (female) said "Aku gak terlalu perhatiin perbedaannya...lebih tertarik hal-hal yang sama yang ada dibuku dan difilm.." ("Actually, I do not notice the differences...prefer to have interest in the similarities on the book and film.."). She told that she was interested to find out the similarities the meaning from Harry Potter book and movie which had the same title. Then, both of male and female students focused on looking the same things from the different sources.

In detaildness, both male $(14,8)$ and female $(10,0)$ students were global. Student A13 (male) said in the interview "Saya cenderung menemukan gambaran besar karena bantu saya dapat kuncikunci didalam detail. Jadi, saya akan lebih mudah mengerti artinya." ("I prefer to find the big picture first because it will help me to get a clue about the details. So, I will be easier to understand the meaning of the context"). He told that finding the big picture first would help him to understand the meaning inside the context of the story. In the inteview, student B3 (female) stated "Makna secara keseluruhann..." ("The overall meaning..."). She told that knowing the main point first would be helpful for her to know the details easily. Ehrman (1996) stated that these learners focused on overall meaning first or big picture. Global learners usually did not focus on details and they would miss some of the details (Ehrman, 1996). 
The questionnaires and interview showed that male students were reflective $(16,3)$. The students indicated as slow. Student A10 (male) said "Saya cenderung mengerjakan tugas sangat lama kak, soalnya saya membaca ulang-ulang setiap soal dan jawaban untuk mengecek dan memastikan kalau itu gak salah." ("I spent a lot of time to do the interview because I always read each question several times and answer time after time in order to make sure or check that the answers are not wrong"). Student A10 told that he needed time to do the exercises because he did not want to make mistakes in answering each questionn. Also, the reflective learners would respond people carefully, they would make sure that they used grammar correctly (Ehrman, 1996).

The last one is concreteness, male $(11,5)$ and female $(8,5)$. Student A11 (male) said "Saya suka bermain online game yang bisa chattingan..." ("I like playing online game which providing a room chat..."). For student A11, he had an activity which was using English as the medium. It was online games, he would like to interact with many foreigners in the games. He would be able to speak English for communication to the members of his groups in the games (Ehrman, 1996). For female, student B6 (female) also liked reading and watching in order to improve her skills. Both of them had their own activities that using English as communication. They apply it based on their interest (Ehrman, 1996).

\section{CONCLUSION}

In the end, the ten sub-scales of cognitive learning styles written by Ehrman (1996) have a great contribution to the second language acquisition. This study shows that gender may have the differences and similarities of cognitive learning styles. The highest sub-scale in common used for male is digital $(18,7)$ and female is analog $(13,9)$. Hopefully, the findings the English teachers especially teaching in 10th-grade to conduct activities based on male and female students' cognitive learning styles.

For further research, it is necessary to have more respondents to distribute the questionnaire for whom want to do quantitative research. With more respondents, it will provide more data. Then, to get more data for doing qualitative research, it also needs more respondents to be interviewed. Besides that, it is important to ask the duration of time that will be given by the school to do the interview so that can have good preparation.

\section{REFERENCES}

Cheeme, I., \& Ridding, R. J. (1991). Cognitive styles: An overview and integration. Educational Psychology, 11, 193-215.

Ehrman, M. E. (1996). Understanding second language learning difficulties. Thousand Oaks, CA: Sage Publications.

Ehrman, M. E \& Leaver, B.L. (2002a). Scoring key: E\&L Learning Style Questionnaire. Retrieved May, 27, 2018, from http://www.cambridge.org/us/download_file/192211.

Ehrman, M. E. \& Leaver, B. L. (2002b). Ehrman and Leaver Learning Style Questionnaire. Retrieved May 15, 2018, from http://www.cambridge.org/us/download_file/192218.

Soozandehfar, D. (2011). The effect of field-dependent/field-independent cognitive styles and gender on second language speaking performance. Retrieved May 21, 2018, from http://www.languageinindia.com/feb2011/fieldindependenceiranfinal.pdf .

Tang, J. (2009). Cognitive style has an effect on learning strategy. Journal of Hubei Radio \&Television University. 29(2), 129-130.

Yayasan Trakanita. (2012). Retrieved November 20, 2018, from http://tarakanita.or.id/beritakegiatan/2012/11/13/pengumuman-lomba-hcpsn-2012.html. 